\title{
The throat of Brazilian Agricole production: The breakdown of vertical silos
}

\author{
Gargalo da produção agrícola brasileira: Colapsos de sillos verticais \\ Cuello de botella de la producción agrícola brasileña: Colapso de silos verticales
}

Received: 06/16/2021 | Reviewed: 06/22/2021 | Accept: 06/23/2021 | Published: 07/09/2021

Karoline Carvalho Dornelas

ORCID: https://orcid.org/0000-0003-3780-913X Universidade Federal de Mato Grosso, Brazil

E-mail: karolinedornelas@ufmt.br

Gypson Dutra Junqueira Ayres

ORCID: https://orcid.org/0000-0001-5260-1682

Universidade Federal de Campina Grande, Brazil E-mail: gypsond@gmail.com

Hygor Cesar Soares Rodrigues

ORCID: https://orcid.org/0000-0002-9829-4101

Universidade Federal de Campina Grande, Brazil E-mail: higor2.soares1@gmail.com

Rafael Torres do Nascimento

ORCID: https://orcid.org/0000-0002-8856-1114

Universidade Federal de Campina Grande, Brazil E-mail: cgtorresrafael@gmail.com

José Pinheiro Lopes Neto

ORCID: https://orcid.org/0000-0003-4960-5679 Universidade Federal de Campina Grande, Brazil E-mail: lopesneto@gmail.com

José Wallace Barbosa do Nascimento ORCID: https://orcid.org/0000-0002-8376-0173 Universidade Federal de Campina Grande, Brazil E-mail:wallacebosa@hotmail.com

\begin{abstract}
In the current world economical conjecture, the accentuated growth in Brazilian production and exportation in the Agro-Food industry sets the country as a central role in the field. Implementing storage units in Agricole properties and industrial sites constitutes a necessary premise to keep the country as a competitive member in the global scenery. The vertical silos present themselves as alternative solutions. However, a great sum of the existent silos does not match the ideal conditions of operation due to the insufficient knowledge of the pressure variations that happen in time and inner space, of the flow, and the variables that affect the behavior of the stored products. Such situations have contributed to accidents and breakdowns in silos. With this increasing demand for the storage capacity in silos, the full understanding of the structural functioning, failure prevention, and optimization of the structural components became of great importance. Thus, this work aimed to present some events that happened in the country in the last years and bring the main causes of structural failures, highlighting the failures that are directly related to the type of flow in the interior of the silo; wacky charging and/or discharging; change in the properties of the stored products (specified weight, actual inner friction angle, friction angle against the wall) and instability in the support columns. It follows that a great number of accidents in these structures could have been avoided or reduced with previous knowledge, from the silo designer and those responsible for the operation, about the most important occurrences in silos.
\end{abstract}

Keywords: Thin-walled metal silos; Buckling failure; Bulk material-silo wall interaction; Eccentric discharge; Rupture.

\section{Resumo}

Na conjuntura econômica mundial, o crescimento vertiginoso da produção e exportação dos setores de agroindústria e de alimentos do Brasil, consolida cada vez mais o país como player fundamental do setor. A implantação de unidades de armazenamento em propriedades agrícolas e plantas industriais, constitui premissa necessária para manter a competividade do país no cenário mundial. Os silos verticais apresentam-se como soluções alternativas. Entretanto, grande número dos silos existentes não apresenta condições ideais de operação devido ao insuficiente conhecimento das pressões que variam no tempo e no espaço interno, do fluxo e das variáveis que afetam o comportamento dos produtos armazenados. Tal situação tem contribuído para os acidentes e colapsos em silos. Com essa crescente 
demanda por capacidade de armazenamento em silos, o entendimento completo do comportamento estrutural, prevenção de falhas e otimização dos componentes estruturais cresceu em a importância. Este trabalho, portanto, visou apresentar alguns eventos ocorridos no país nos últimos anos e abordar as principais causas das falhas estruturais, destacando-se as falhas relacionadas diretamente ao tipo de fluxo ocorrido no interior do silo; carregamento e/ou descarregamento excêntrico; alteração nas propriedades dos produtos armazenados (peso específico, efetivo ângulo de atrito interno, ângulo de atrito coma parede) e instabilidade dos montantes. Conclui-se que grandes números de acidentes destas estruturas poderiam ser evitados ou atenuados com o conhecimento prévio, por parte dos projetistas e responsáveis pela operação, sobre os fenômenos mais importantes em silos.

Palavras-chave: Silos metálicos de paredes finas; Falha por flambagem; Atrito do produto com a parede do silo; Descarga excêntrica; Ruptura.

\section{Resumen}

En la coyuntura económica mundial, el vertiginoso crecimiento de la producción y las exportaciones en los sectores agroindustrial y alimentario de Brasil consolida cada vez más al país como un actor clave del sector. La implementación de unidades de almacenamiento en predios agrícolas y plantas industriales es una premisa necesaria para mantener la competitividad del país en el escenario mundial. Los silos verticales se presentan como soluciones alternativas. Sin embargo, una gran cantidad de silos existentes no presentan condiciones ideales de operación debido a un conocimiento insuficiente de presiones que varían en el tiempo y espacio interno, flujo y variables que afectan el comportamiento de los productos almacenados. Esta situación ha contribuido a accidentes y derrumbes en silos. Con esta creciente demanda de capacidad de almacenamiento en silos, ha cobrado importancia una comprensión profunda del comportamiento estructural, la prevención de fallas y la optimización de los componentes estructurales. Este trabajo, por lo tanto, tuvo como objetivo presentar algunos hechos ocurridos en el país en los últimos años y abordar las principales causas de fallas estructurales, destacando las fallas directamente relacionadas con el tipo de flujo ocurrido dentro del silo; carga y / o descarga excéntrica; alteración de las propiedades de los productos almacenados (peso específico, ángulo de fricción interno efectivo, ángulo de fricción con la pared) e inestabilidad de las cantidades. Se concluye que gran cantidad de accidentes en estas estructuras podrían evitarse o mitigarse con un conocimiento previo, por parte de los diseñadores y responsables de la operación, sobre los fenómenos más importantes en silos.

Palabras clave: Silos metálicos de paredes delgadas; Falla por pandeo; Interacción entre el material a granel y la pared del silo; Descarga excêntrica; Ruptura.

\section{Introduction}

In the current world economical conjecture, the accentuated growth in Brazilian production and exportation in the Agro-Food industry sets the country as a central role in the field, with an estimated harvest of 265,9 million tons in the 2020/2021 period, with a highlight for the corn and soy commodities, which correspond to 89\% of the production (Conab, 2021). The fact that the country became a great producer of grains and their derivates, stresses the concerns regarding storage, in which, besides the excellence in terms of production, an investment in silos is necessary (Baroni et al., 2017), pointing them as fundamental elements in the production chain.

The silos are structures aimed at the storage of grain- or powder-like products, they can be built of multiple materials. Currently, industrial storage silos are usually built of wavy plates reinforced by vertical columns, since they offer a quick assembly and a low cost with steel in comparison to usual flat-wall silos (Sondej et al., 2015). Concerning the structural efforts, the silo walls are submitted to horizontal pressure and friction against the stored solids and are projected to transmit the compression tensions in a vertical direction; and the traction tensions in a circumferential direction (Iwicki et al., 2015).

The structural failures that affect metal silos in Brazil are not always clear. This happens because such events are not reported, contributing to the fact that this problem is poorly evidenced and studied by the scientific community.

In this sense, it can be observed that projects of silos establish themselves almost always as correct, dispelling their real structural problems and hindering the proper and necessary intervention of the scientific community with concrete studies in this theme.

Therefore, it is evident that the inexistent development of standards dealing with the design of silos in our country by the Brazilian Association of Standards and Techniques-ABNT is not just one of the problems, also, there is still a great gap left by companies that produce silos in Brazil, which are mostly foreign and, for marketing reasons, suppress the methods used to 
the design of their structures during investigations.

Like all other engineering structures, the starting point for structural analysis in the design of silos is the determination of the actions acting during the life cycle of the structure, which can be classified as permanent, variable, and exceptional (Tascón, 2017; Mehretehran \& Maleki, 2018). Due to the diversity of combinations of actions to which these structures can be submitted (Jansseune et al., 2015), there are different failure modes, resulting in environmental damage, economic impacts, and, in some cases, claiming lives (Colonnello \& Kramár, 2018).

Official records of the occurrence of silo collapses are scarce, since the companies responsible for the design, manufacture, and assembly do not disclose the cases, to protect their commercial brands, besides that, multiple accidents have been registered across the whole national territory. It should be noted that the failure rate in silos is much higher than that found in other industrial buildings (Livaoglu \& Durmus, 2016; Zaccari \& Cudemo, 2016) mainly due to design errors, execution errors, improper use, and/or absence of maintenance. These failures can consist of minor localized damage until the complete collapse of the structure. The objective of this work is to present the main causes of structural failures presented in silos for the storage of agricultural products in Brazil.

\section{Methodology}

This literature review is an exploratory and informative case study (Ludke \& Andre, 2013; Pereira et al., 2018) presenting a comprehensive explanation for the main causes of collapses in vertical silos, it is a study that will contribute to silo projects. A research was carried out for works related to the proposed subject, critically selecting impactful articles, reports and scientific papers that address the theme, characterizing itself as a qualitative research (Ludke \& Andre, 2013; Pereira et al., 2018).

It starts with a walk through the existing literature in a historical perspective of the characterization and importance of silos, followed by an explanation of accidents with silos that have occurred in Brazil in the last five years (2016-2021) and an in-depth study of the main causes of collapse in silos. The articles chosen for the preparation of this work were taken from the respective databases: Elsevier, Google Scholar, Capes Periodicals, Pubmed, Scielo, Scopus and Science Direct, in which syntheses of prioritized knowledge were elaborated among the articles of the last fifteen years (2006 -2021), without disregarding relevant work from previous years.

It can be verified that the ignorance about the structural behavior of vertical silos and the way they are being used lead to a high risk of accidents, showing clearly the need for improvements in the project, assembling, operation, and maintenance, in such a way that they suit the way which national companies store their products in these structures. it is important to point that the events presented show a small part of the incidents which can be observed, highlighting the need to look after a rule for shaping vertical silos according to the reality of the country.

\section{Main Causes of collapses in silos}

According to Lopes Neto and Nascimento (2018), the causes of failures in silos are classified as functional and structural, and structural causes may be inherent to functional problems since the silos are requested mechanically from the contact of their constituent parts with the stored product and, if this contact is unpredictable and disordered, making it difficult to correctly dimension it, silos can become unstable and very dangerous structures. Besides, the company and the contractor face possible legal issues in terms of liability exposure (Dogangun et al., 2009). And consequently, the direct and indirect costs associated with the failure of a silo are, in most cases, considerably large (Colonnello \& Kramár, 2018; Dogangun et al., 2009). The main types of structural failures found in vertical silos in Brazil are: 
-Failures related directly to the flow type in the interior of the silo;

- Abnormal loading and unloading;

- Change in the properties of the stored product (exact weight, effective inner friction angle, friction angle against the silo wall);

- Incorrect dimensioning and instability in the columns.

However, the primary precautions remain the most important in the use of these structures, among them the determination of the flow properties of the range of products to be stored, a design of the flow that encompasses all the possibilities of use related to the time and ways of loading and unloading. and in-depth knowledge of the actions likely to occur, as well as the correct security protocol for constant verification of structural integrity (Lopes Neto \& Nascimento, 2018). The following are reports of some accidents that have occurred in Brazil in recent years.

On November 25, 2016, two metal silos with a capacity to store 5,000 bags of corn each, collapsed in Tangará da Serra - MT, leaving a fatal victim (Figure 1). The worker was cleaning the place when the structure collapsed, according to reports, in an attempt to escape the first collapse the victim was surprised by the fall of the second silo.

Figure 1. Silo in Tangará da Serra- MT.

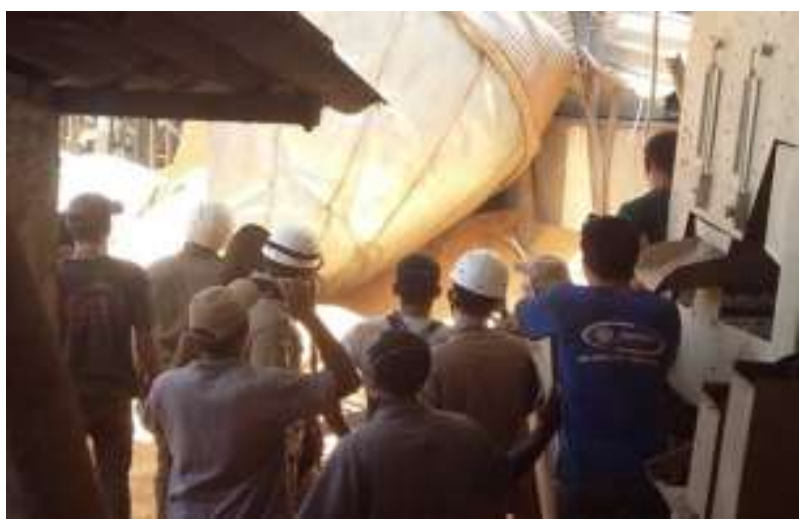

Source: Canal Rural (2016).

In addition to the Fire Department, company employees helped to rescue the worker (Figure 1). It can be seen from Figure 1 that the structural failure in the first silo caused the spread of the damage in a chain reaction, resulting in the collapse of the entire structure, and culminating in the loss of a life.

On April 6, 2017, a metallic silo that stored wheat bran in Faxinal - PR collapsed on top of the truck (Figure 2), there was an employee inside the vehicle that was buried. 
Figure 2. Silo storing wheat bran in Faxinal - PR.

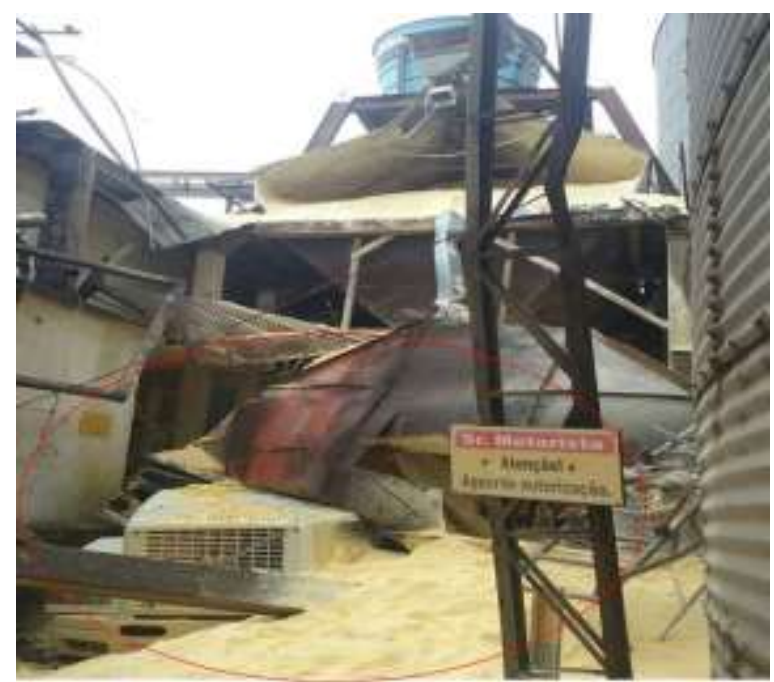

Source: O Bem Dito (2017).

Figure 2 shows the wreckage of the structure and the product above truck, as shown by the red circle. the breakage of the structure may have been caused by the collapse of the vault, due to the stored powder cohesive properties. according to Cheung et al. (2015) a large number of silos have deformations at its bottom and sides due to the collapse of vaults from cohesive products.

On August 8, 2018, a silo that stored corn in a factory located in the city of Campina Grande - PB, broke down and buried an employee (Figure 3).

Figure 3. Silo breakdown in Campina Grande - PB.

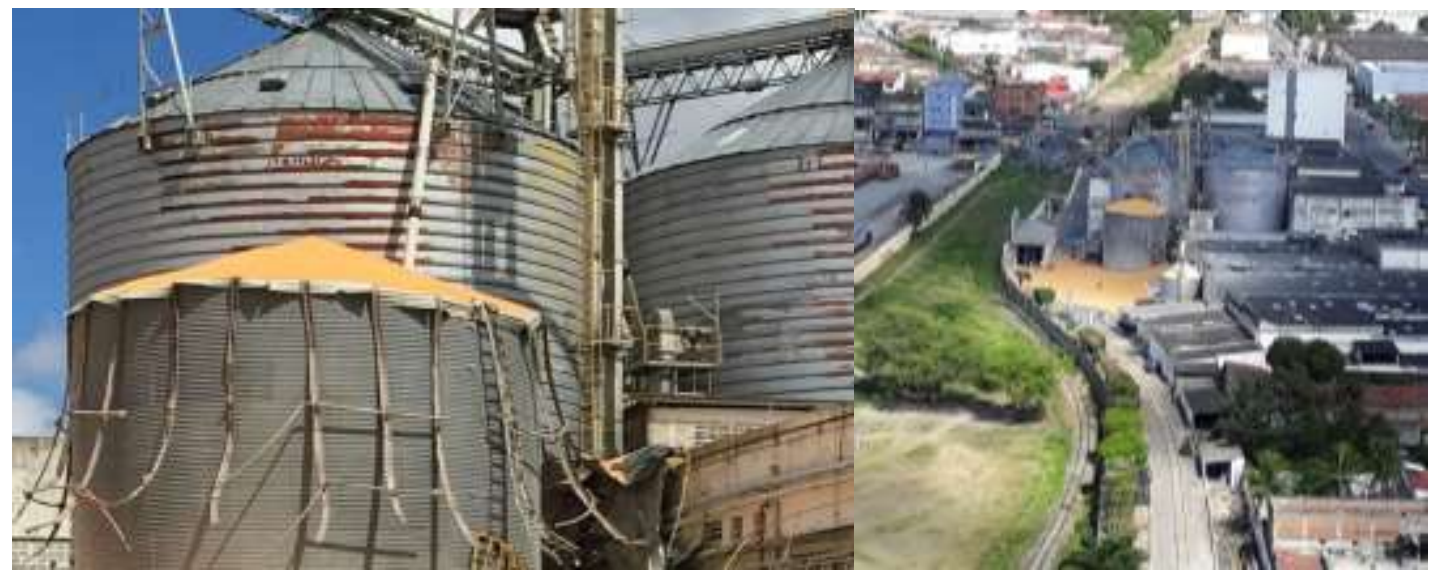

Source: ClickPB (2018).

The image on the left (Figure 3) shows the silo after the collapse, with part of the granular product still inside, and the right side, the aerial image of the product spread across the factory yard after the accident.

On November 18, 2019, in Passo Fundo-RS, as determined by the Civil Police, an employee carried out the loading of a feather meal silo - used for animal feed - manually through a hatch. The estimate is that there were, at that time, 40 tons of the product, for a capacity of 50. People who were at the site reported that an explosion followed by a flash in the silo. Then the entire structure collapsed, including the platform on which the victim was. 
Figure 4. Accident with a fatal victim inPasso Fundo - RS.

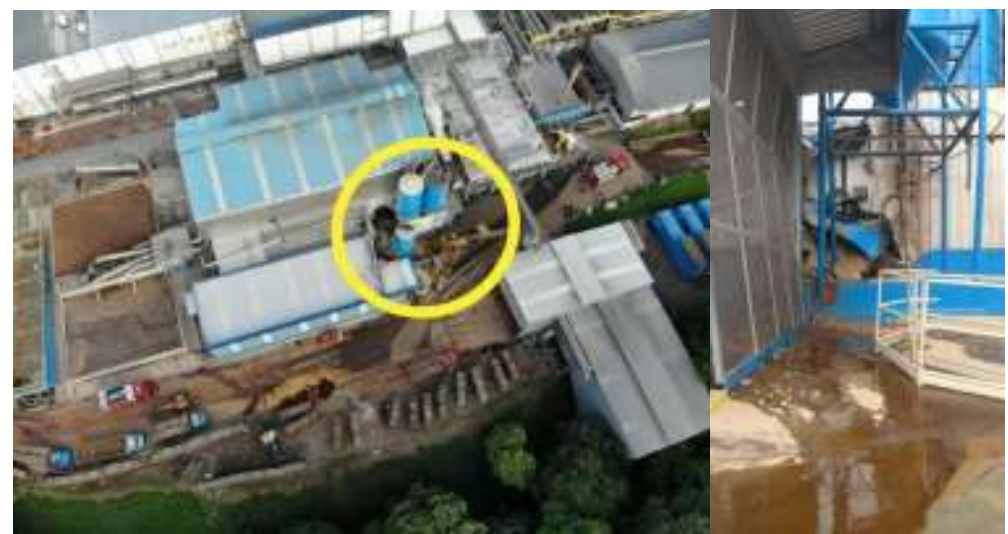

Source: Portal Tchê (2019).

The yellow circle shows the placement of the broken silo on the factory premises (Figure 4). The image on the right side allows a frontal view of the debris after a possible explosion (Figure 4). Lopes Neto \& Nascimento (2018) state that explosions are one of the most common causes of accidents involving these structures. Calil (1982) states that the fine particles of many stored materials can form clouds of explosive dust when suspended in the air, whereas, if ignition occurs, the heat produced by the combustion of the particles of the powdery material, sometimes combined with the reaction of gaseous products, can cause a rapid increase in the pressure of the structure and result in an explosion of the silo, measures must be taken against the danger of dust explosions (apart of ignition sources, control with welding works, etc.).

On August 15, 2020, a silo loaded with corn kernels broke and spread the entire load in the courtyard of a private company, with no fatalities (Figure 5). The incident happened in the Eldorado District, which belongs to the municipality of Tapurah - MT.

Figure 5. Debris from the silo that broke in MT.

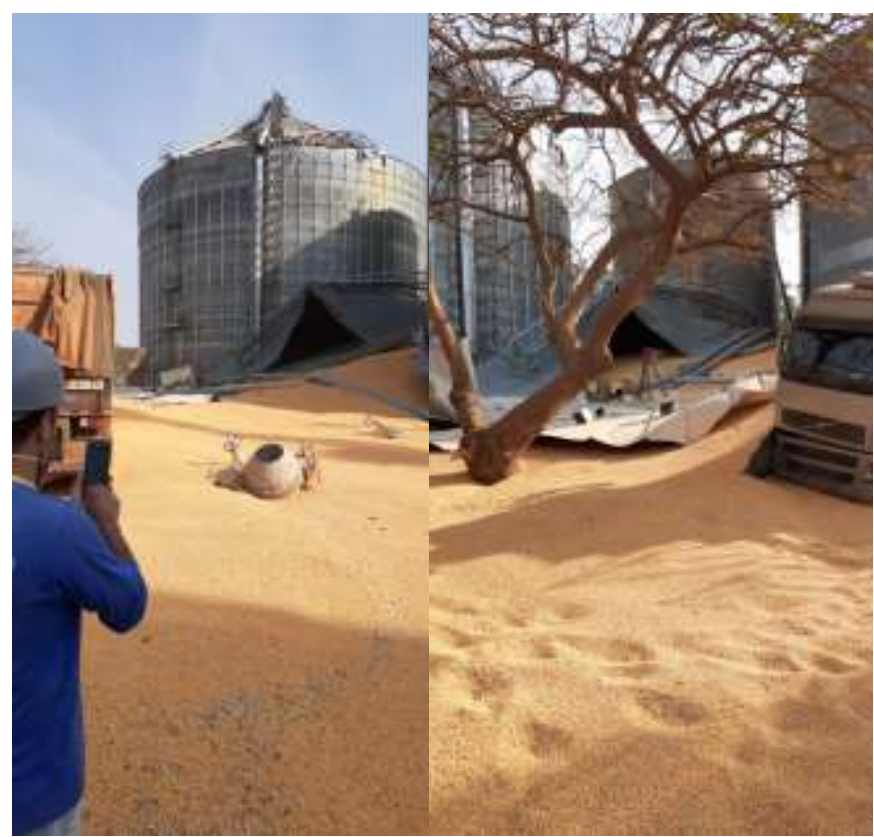

Source: Tangará em foco (2020). 
The structure after the collapse is shown by different angles in Figure 5, the wreckage indicates a structural deficiency in the stiffeners and side plates.

On January 10, 2021, another fatal victim was registered in a silo accident in Brazil. In the city of Ypê - RS, according to a record from the Fire Department, an employee was inside a silo that stored soybeans, breaking clods of grain that accumulated and did not pass through the grain elevator. The boy ended up falling into an air pocket and being buried by the product (Figure 6).

Figure 6. Detail of the opening at the bottom of the structure for removing soybeans and rescuing the victim.

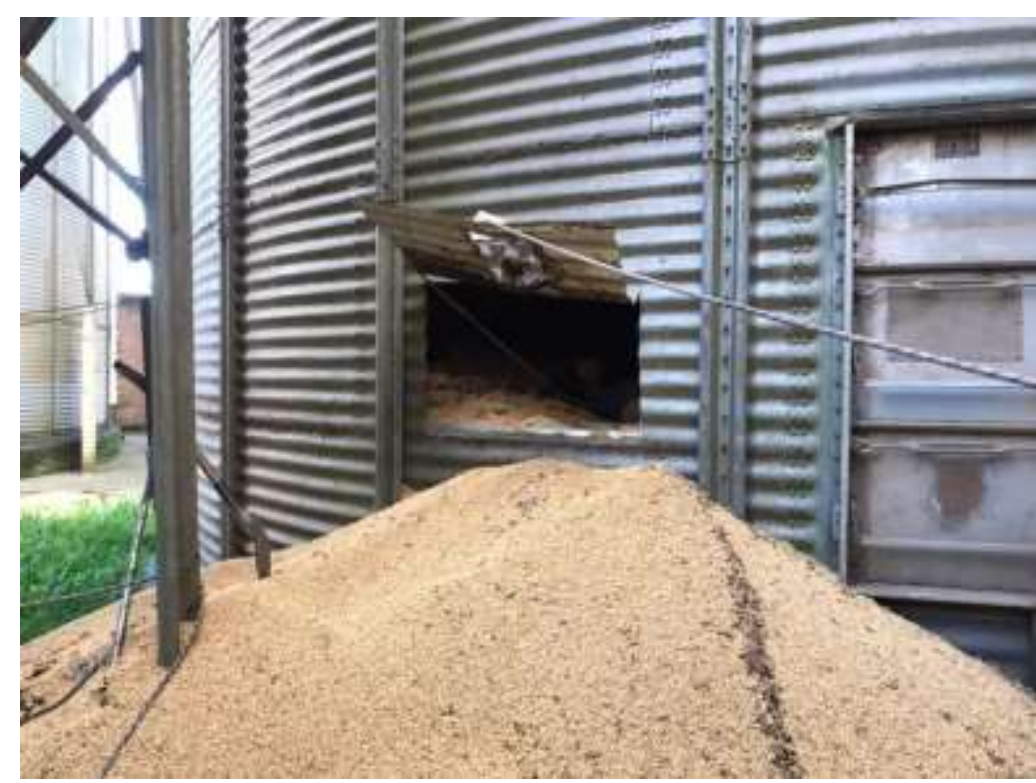

Source: Gaucha ZH (2021).

The cut made by the Fire Department at the bottom of the structure in order to empty the silo and remove the victim is shown in Figure 6. Cheung et al. (2015) state that soybean consolidation occurs due to the formation of cohesive mechanisms, possibly arising from the high moisture level (above the upper limit defined in the project).

\section{Flow in Silos}

The occurrence of flow obstructions in silos happens because the stored product acquires sufficient strength, when consolidated, to support its weight (Oginni \& Fasina, 2018). Thus, in the design of silos, the main objective is to guarantee that the stored material will flow without obstructions. However, a large number of existing silos do not have ideal operating conditions due to insufficient knowledge of the variables that affect the behavior of products, the correct flow prediction, and, consequently, the pressures, contributing to accidents and collapses in silos (Paula, 2020).

The gain or not of this resistance depends on the combination of several factors, such as percentage and distribution of the size of fine particles, moisture content, storage time, presence of clays or talc, and the chemical nature of the product. If the material gains resistance, problems of obstruction in tube or arc (cohesive or mechanical) can occur, depending on the inclination and geometry of the hopper, dimensions of the discharge hole, wall roughness, and the flow pattern developed by the product (Cabrejos Marín, 2018).

If during product unloading, none of these obstructions occur, it is assumed that a satisfactory flow will occur. Obstructions provide serious damage to healthy silos and, above all, to the hopper, because when they break, they operate like 
pistons, compressing the air in the hopper, leading to damage to the sidewalls and discharge hole (Deckers, 2014).

Flow obstructions, such as the formation of cohesive arcs and interruption of the discharge of the silo, can promote the total or partial stop of the discharge, and if the silo is located in the production and/or distribution sector, it will result in losses due to the increase of production costs, causing a process of industry discontinuity in the medium term (Silva, 2019).

In this sense, understanding the product flow behavior is essential to identify possible segregation and discharge problems. In many cases, there is a need to improve the flow discharge regime to obtain sufficiently uniform product storage time, avoiding the formation of stagnant zones, or reducing the segregation (Silva, 2019).

The tube effect occurs substantially in the funnel flow, being characterized by the stagnation and conservation of a large part of the product adjacent to the formed discharge tube across the entire height of the silo, providing incomplete discharge of the material (Cabrejos Marín, 2018). The occurrence of the tube effect is due to an intimate association between the particles of cohesive products, being discharged into silos equipped with hoppers with a high angle of inclination in relation to the vertical, and rough walls (Lopes Neto et al., 2007).

Cabrejos Marín (2018) states that it is very difficult to produce the flow of this material that stays stable around the channel by external means, such as vibrations or manual interference. Depending on the roughness of the walls and the hopper slope, the silo may or may not empty. It must be ensured that the product is unable to acquire sufficient strength to support its weight due to consolidation. In general, funnel flow silos are only suitable for granular, free-flowing, or slightly cohesive materials and when the segregation occurrence is not important (Cabrejos Marín, 2018).

This type of obstruction can be extremely damaging to the silo structure if the material begins, at first in the stagnant condition, to move in the axial direction. If this occurs, the first layers moved will cause air suction in the upper part of the silo body and will provide an abrupt expulsion of the air contained in the tube, which may cause deformations and rupture of the walls, in the hopper-body transition zone of the silo, in the orifice. and discharge devices (Medeiros, 2012).

Lopes Neto and Nascimento (2013) studied the storage in silos of three products used in the agricultural environment, being them: corn in grains, crushed corn, and soybean meal. The authors used a metallic silo in a reduced model with a semicircular cross-section with the front face closed by a translucent glass wall, allowing the visualization of the flow formed. With the use of a concentric hopper with a horizontal inclination of $70^{\circ}$, it was found that for crushed corn, the flow started with the formation of a vertical and central flow channel propagating upwards until reaching the surface higher than the stored mass. The authors also noted that the unloading occurred through successive attempts to form the tube effect and frequent collapse of the sidewalls when they reached an average formation height of $45 \mathrm{~cm}$, this behavior not being observed for the other analyzed products.

Cohesive arches can take on different configurations, according to the used hopper geometry, with the appearance of cohesive arches called "bridge" in wedge-shaped hoppers and vault or dome arches in symmetrical axis hoppers (Medeiros, 2012).

When a cohesive arc forms in a hopper, the resulting force from the weight of the stored product is transferred to the hopper walls and, when it breaks, this force is directed to the silo body (Lobato et al., 2016). Generally, products with fine and cohesive granulometry present this type of obstruction, requiring larger dimensions of the discharge orifice and inclination of the hopper, to avoid arching problems (Park, et al., 2016).

Lopes Neto (2009) points out that cohesive arches are one of the main obstacles faced by industries that handle powdery products. Batista (2009) states that the product's storage time must be carefully analyzed, as it considerably affects the type of flow and favors the formation of cohesive arcs. According to the author, the longer the product period inside the silo, the greater the gravity action on all layers of the stored product, consequently, the greater the level of compaction of its 
particles, facilitating the formation of arcs.

In contrast, the mechanical arc-type obstruction is caused by the interlocking between the particles of larger granulometry when compared to the size of the discharge orifice. When the flow starts, the larger particles are prevented from moving in the axial direction and from rotating with each other, especially when the empty spaces between these particles are filled by smaller-sized particles (Ravenet, 1983).

\section{Abnormal Loading and Unloading}

The structural integrity of the silo depends on the amount of pressure exerted by the stored material, it is essential to understand and quantify the maximum pressures in the project (Oginni \& Fasina, 2018). However, according to Lopes Neto et al. (2014), the knowledge of its maximum values is not enough to guarantee a well-developed project, since loading and unloading eccentricities can lead to the development of unanticipated and uneven actions along the depth of the silo wall, which, in the case of frictional forces, can generate diametric bending moments and localized buckling.

The opening of the discharge orifice generates a decrease in the vertical pressure that can be accompanied by an increase in the horizontal pressure depending on the height-diameter (H / D) ratio, and geometry and size of the silo, with pressure peaks being found in the range of 1.1 to 3.9 (Kobyłka et al., 2017). Non-uniform tension states in grain silos are believed to be the cause of many structural failures (Kobyłka et al., 2020).

Cao and Zao (2017) report that the eccentricity in both loading and unloading can result in a significant reduction in the lifespan of the structure. The eccentric discharge becomes interesting because it allows the optimization of the use of conveyors in addition to facilitating the access of trucks and trains when unloading the product (Madrona \& Calil Junior, 2009). However, the incidence of silos failures under an eccentric discharge condition is much higher than in concentric conditions (Maiti et al., 2016).

This high failure rate is mainly related to the complexity of the pressures exerted by the product during eccentric discharge and the difficulty in understanding the pattern of the tensions that develop on a thin wall under such asymmetric pressure regimes (Sielamowicz et al., 2010; Sadowski \& Rotter, 2011). Because the horizontal pressure distribution is not uniform across the circumference of the silo, the topic has motivated studies on eccentric discharges (Maiti et al., 2016).

Eccentric discharges can either be projected or occur accidentally. When designed, they must follow the parameters indicated by the standards. Foreign normative codes usually address symmetrical axial tension states and even avoid defining eccentric discharge pressures due to uncertainties associated with flow patterns. The EN 1991-4 norm, is one of the few that presents definitions about the geometry of the flow channel and the pressures of the wall under eccentric discharge (Sielamowicz et al., 2010).

Zaccari and Cudemo (2016) state that the description of asymmetric pressures contained in the European normative code EN 1991-4 enables the development of relatively realistic calculations for this event and point out that, for the old silos (not designed based on the updates to the normative codes), a possible reinforcement of the 'husk' can be considered as a preventive measure to reduce the risk of silo failure.

On the other hand, the incidence of accidental eccentric discharge can occur due to blockages, malfunction of the silo extraction thread, and segregation of the material due to humidity or different densities, among many other causes (Sadowski \& Rotter, 2011). Sadowski and Rotter (2011) show that the failure under eccentric discharge occurs due to buckling, due to the development of highly asymmetric horizontal pressures, which contributes to the meridional flexion and asymmetric distribution of the compression forces on the wall, which leads to many serious and catastrophic failures. Even for silos designed for concentric discharge, the effects of eccentric discharge are difficult to avoid due to material segregation. 
Lopes Neto et al. (2014) analyzed the vertical and frictional forces in a cylindrical silo with a flat bottom, being loaded concentrically and discharged concentrically and eccentrically, from two eccentricities, with the experimental values compared with those prescribed by the standards ENV 1991-4, ISO 11697, AS 3774 and DIN 1055. The authors observed that compared to the frictional force in the concentric and eccentric discharge at 75\%, multiple discharges produced values about $30 \%$ higher and that eccentric discharge presented their values underestimated by all standards in the depth of $1.00 \mathrm{~m}$ with a difference of up to $48.8 \%$.

Zaccari and Cudemo (2016) evaluated a case of silo collapse that stored limestone. The structure weighed in its entirety about 11,000 tons (accounting for product and metallic structure), being built with a wall plate thickness gradually varying from $8 \mathrm{~mm}$ (top) to $20 \mathrm{~mm}$ (silo base). The silo presented plastic deformation of the typical shell of buckling phenomenon, and the authors found that the failure occurred due to the eccentric discharge. In the case under study, it was found that the collapse by eccentric discharge had two determining factors, namely:

1. Project error: incorrect sizing, silo designed in the '90s with old design pattern - effect of loading and unloading eccentricity treated as an additional component. A simple patch of normal pressures of prescribed magnitude, distribution, and location was implemented in the project. This approach proved not to be adequate to represent the actual pressure pattern that causes the buckling load;

2. Usage error: the silo was equipped with six discharge points at the bottom, but, due to the obstruction of the material, a preferential outlet was established.

In general, to avoid this type of instability it is necessary, in the design phase, to characterize the pressure distribution caused by the eccentric flow of products in the best way possible (Zaccari \& Cudemo, 2016), and it should be noted that a project elaborated conservatively under concentric discharge is far from safe under eccentric discharge. This pressure pattern completely surpasses the safety coefficient that the silo would present under concentric discharge and would cause a very early elastic buckling failure. The cause of this initial failure is the development of high axial compression tensions in a large part of the silo wall, close to the central part of the flow channel, with its peak at approximately half the height (Sadowski \& Rotter, 2011).

It is noted, therefore, that the main problem of eccentricity does not lie in the pressure values, but in the asymmetry of the same, which generates ovalization of the silo walls, an effect that is accentuated with slenderness (Madrona \& Calil Júnior, 2009). A method of adopting coefficients that increase the pressure on the side opposite the eccentricity and lessen the pressures on the adjacent side can configure an adequate alternative to cover the larger eccentricities, reducing failures and collapses in silos.

\section{Alteration of the Physical and Flow Properties of the Products}

In the design of silos, the determination of the properties of the product to be stored is fundamental for understanding the flow and calculating the pressures that will occur during the loading, storage, and unloading operations, in such a way that an economical, safe and durable structure is obtained. (Alonso-Miravalles et al., 2020). The lack of information on the part of the designers of the physical properties of the stored product and the influence on the humidity in the behavior of the tensions within the product significantly affect the pressures, leading to structural collapses, which are the most evident problems in the studies about accident causes and collapses in silos carried out by Cheung et al. (2015).

The main physical properties of the products which are determined and used for the design of flow and silo structures are: consolidated specific weight $(\mathrm{g})$; granulometry (dmax and $\mathrm{dmin})$; moisture content $(\mathrm{w})$; internal friction angle $(\phi \mathrm{i})$; effective internal friction angle ( $\phi e)$; internal friction angle of the product with the wall ( $\phi w)$ and flow function (FF) (Fürll \& 
Hoffmann, 2015; Stasiak et al., 2015; Calderón et al., 2017; Malagalage et al., 2018). Factors such as room temperature, moisture content of the product, and storage period can significantly influence the results of the tests. Therefore, the tests should be conducted as close as possible to the conditions expected for the storage of the product (Chen et al., 2018).

The consolidated specific weight is a property that can be changed by the degree of product compaction resulting from its moisture, overpressures that occur in the silo, storage time, rate, the way the loading happened, and height of the product's fall (Fürll \& Hoffmann, 2015). According to Calil Júnior (1990), there is no direct relationship between specific weight and flow prediction, however, its determination is essential because it is an important parameter for calculating the pressures acting on walls and silos hoppers (Jager et al., 2015) besides the silo capacity estimate (Stasiak et al., 2015).

Granulometry characterizes one of the properties that have a direct influence on the flow pattern, determining the type of flow (Jager et al., 2015). Products classified as granular are generally free-flowing, whereas fine-grained products commonly show less fluidity due to cohesion (Siliveru et al., 2017).

Mellmann et al. (2013) studied the effect of the shape and granulometry of different granular producers (wheat, barley, oats, and corn) on the flow properties, with two particle sizes evaluated, from 0.315 to $0.5 \mathrm{~mm}$ and 0.5 to $0.8 \mathrm{~mm}$. The authors found an increase in fluidity for the largest particle size range (0.5 to $08 \mathrm{~mm})$ since they present non-cohesive properties. In terms of shape, the results revealed that the fluidity of the crushed grains decreased the further the shape of the particles moved away from the spherical shape.

Liu et al. (2015) evaluated the effect of granulometry on the fluidity of powdered coal. The authors observed during the experiment a progressive transition from mass flow to mixed flow and complete obstruction as the particle size decreased. Coal whose particles had a diameter greater than $100 \mu \mathrm{m}$ obtained mass flow, with a diameter between 40 and $100 \mu \mathrm{m}$ showed unstable flow, and the formation of cohesive arc was obtained for the product whose diameter was less than $40 \mu \mathrm{m}$.

Stasiak et al. (2015) determined flow properties for sawdust and wood chips with different moisture content. The increase in the moisture content of both materials increased the consolidated specific weight and a reduction in fluidity.

The determination of humidity is fundamental, constituting a property that directly affects the density, durability, and fluidity of the product (Ripp et al., 2015). The increase in humidity associated with the storage time hinders fluidity, increasing the possibility of the occurrence of flow obstructions, especially for powdery products (Mitra et al., 2017).

For Nascimento (1996) under high levels of humidity and adverse atmospheric conditions, the grains can undergo fermentation, acquiring resistance and ceasing to be free-flowing. Soy flour contains oil, and its particles join under conditions of high temperatures and moisture rate, forming a difficult flow mass. Souza et al. (2015) state that for safe storage, the grains must have between 13 and $14 \%$ of moisture on a humid basis.

The Australian standard AS 3774 (1996) foresees an increase in pressure on the walls of the silo when an expansion of the stored product occurs due to the absorption of moisture, describing the changes that occur in the horizontal pressure and frictional force on the walls, being valid when the variation of the moisture content exceeds $1 \%$ after product storage.

The American standard ANSI / ASAE EP433 1988 (R2011) does not present any approach on the calculation of pressures regarding the elevation of the moisture content of the product, informing only that the moisture content during storage can increase by $4 \%$ or more, providing an increase in lateral pressures under static conditions. It is reported by the American norm that an increase of $4 \%$ in the moisture content provides a lateral pressure six times greater, and for an increase of $10 \%$ in the humidity of the product after storage, the pressure increases by a factor of 10 . Depending on the potential for high loads, it is recommended that silos are designed, located, and handled in such a way as to avoid an increase in moisture content above $1-2 \%$ during storage. 
The internal friction angle refers to the internal conditions of the product in the storage condition, that is, the friction between the particles, and the effective internal friction angle is used to estimate the flow conditions. With this parameter, the maximum angle of inclination of the hopper wall in relation to the vertical is determined, to obtain the desired flow pattern (Stasiak et al., 2015), constituting properties that provide a theoretical basis for the silo design, making the design of structures and equipment for handling and transporting materials more accurate and suitable for real situations (Chen et al., 2018) and, reducing the incidence of failures and collapses.

Special attention should be paid to the friction angle of the product with the wall, both for determining the geometric characteristics of silos, as well as hoppers (minimum angle) and dimensions of the discharge orifice, representing the adhesion effort between the stored product and the surface of the wall material (Lopes Neto et al., 2007; Jager et al., 2015). Knowledge of this parameter is essential for the elaboration of structural and stability projects.

The composition, moisture content, and particle size distribution of the products will influence their characteristics of friction with the wall. Smaller particles tend to increase the friction with the wall since there is a greater contact surface area between the particles and the wall surface (Iqbal \& Fitzpatrick, 2006). Corroborating with that found by Ripp et al. (2015), when analyzing granular products (wheat seeds) and powdery products (wheat flour). Regardless of the wall material, the authors found that the angles of friction with the wall were greater for the flour than for the seeds, influencing the hopper angle.

Silva et al. (2011), analyzed coffee grains with different moisture content and claim that the increase in the friction of the product with the wall due to the water content happens possibly since products with higher moisture content generate greater forces of adhesion and cohesion between the grains and also between product and the contact surface.

Liu et al. (2015) found different relationships between the friction angle of the product with the wall and the particle size. Within the coarse particle range $(>100 \mu \mathrm{m})$, the wall friction angle for pulverized coals was relatively low and independent of the particle size. On the other hand, for fine particles, the angle of friction with the wall increased exponentially with the decrease in the size of the particles, indicating that the friction between the wall and the product will be the main effect on the behavior of the pulverized coal flow.

Jager et al. (2015) observed in their studies that the wall friction angle increased with the decrease in the consolidation tension. At low values of consolidation tensions, the particles of the material did not undergo appreciable deformation and their surface roughness remained relatively intact, resulting in greater friction with the material of the hopper wall. At higher values of consolidation tensions, the particles began to deform in flatter and smoother bodies, resulting in less friction with the hopper wall material. For this reason, the ratio of friction / adhesion forces to the consolidation tension becomes greater with the decrease in the consolidation tension, because the friction and adhesion forces do not decrease proportionally to the applied tension.

The flow function (FF) characterizes the product's ability to flow by gravity (flowability measure) (Guo et al., 2018). Each stored product has its flow function and flow function over time. The determination of these relationships is crucial in the design of a silo, to prevent flow problems and, consequently, possible failures that can lead to the collapse of structures.

The greater the consolidation of the product that is stored, the greater will be its consolidation tension, its density, and undefined rupture stress. Free-flowing (non-cohesive) products exhibit virtually no breakdown tension value, even for large consolidation conditions. On the other hand, most cohesive products have an unresolved rupture tension when consolidated. The FF values were classified by Jenike (1964) from its limit. According to Jenike's fluidity rating, a higher FF value means easier flow. When the FF is in the 4-10 range, the particles flow easily. When the FF is in the 2-4 range, fluidity is reduced, due to the cohesive properties (Guo et al., 2018). 


\section{Columns Instability}

Many collapses of metallic silos in the country have been recorded due to the instability of the columns. These work, mostly, to compression, being responsible for resisting the frictional forces existing between the stored product and the silo wall (Rodrigues, 2019). Current Brazilian standards do not provide specific recommendations for calculating the critical buckling strength of these profiles when used in metal silos with corrugated sheets (Rodrigues, 2019).

According to Calil and Cheung (2007), there are many doubts about the buckling length of the column, and still, they report that it is very common to admit the buckling length equal to the height of the silos plate when dimensioning. Due to the absence of design criteria, Rodrigues (2019) proposed the development of methods for the analysis of the instability of the columns taking into account the influence of the corrugated/corrugated wall stiffness on the column behavior. It was found by the author that among the evaluated methods, the greatest difference found was $10.39 \%$ between analytical and experimental tests, however, the data provided by the B method of the Eurocode 3 standard had critical buckling load values of $12.48 \mathrm{kN}$, approximately $83 \%$ of error in comparison to the experimental values.

Much research with simulations and experiments has been taking place in the scientific community about the approach employed by Eurocode 3 on the analysis of the instability of metal silos columns, with two methods (A and B) being defined for the calculation of the critical buckling load (Rodrigues, 2019). Iwicki et al. (2015), Hotala et al. (2016), and Rejowski \& Iwicki (2016) concluded that Method B as proposed in the Eurocode 3 normative code is extremely conservative.

Numerical analyzes using the ABAQUS software, considering the geometric and physical nonlinearity of the material, indicated the use of Eurocode 3 Method A regardless of the distance between the columns, that is, the analysis of the instability of the columns would always be based on the orthotopic shell theory, whose results were closer to those found in numerical analyzes than using Method B as proposed in Eurocode 3 (Iwicki et al., 2015). Rejowski \& Iwicki (2016) performed finite element numerical analyzes for dimensioning columns and the results found showed an error of approximately $20 \%$ compared to Method B proposed in Eurocode 3.

Incorrect dimensioning and local instability of the columns was documented by Cheung et al. (2015) in a metallic silo with $22 \mathrm{~m}$ in diameter and $24 \mathrm{~m}$ in height, with a storage capacity of $8400 \mathrm{t}$ of wheat grains. This structure located in Brazil, presented deformations located in the columns (local instability), as shown in Figure 7. The authors performed the calculation of the acting pressures and structural verification employing numerical simulations, verifying that the columns did not provide satisfactory security for absorption of the frictional forces mobilized between grains and the corrugated silo wall.

Figure 7. Deformation of the column due to local instability.

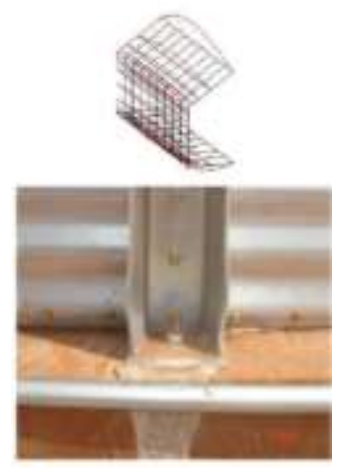

Source: Cheung et al. (2015). 


\section{Conclusion}

Looking at the main factors that lead to the structural collapse of silos in Brazil which were presented. It follows that a large number of accidents in these structures could be avoided or mitigated with prior knowledge, by the designers and those responsible for the operation, about the most important phenomena in silos (structural behavior, physical and flow properties of stored products, and operation structure).

It appears that the lack of knowledge about the structural behavior of vertical silos and the way they are being used in practice, result in high risks of accidents, with a clear need for improvements in design, assembly, operation, and maintenance, in such a way that they are appropriate to how national companies store their products in these structures. It should be noted that the events presented represent a very small portion of the accidents evidenced in practice.

New research must be carried out on the subject, a suggestion for further studies would be the determination of more detailed criteria for the design, assembly and maintenance of vertical silos, aiming to increase safety in the procedures for their use, and adapting to the way in which Brazilian companies employ these structures for the storage of their products.

\section{Acknowledgments}

To the Institute of Agrarian and Environmental Sciences (ICAA) of the Federal University of Mato Grosso, for having granted leave to pursue a doctorate to the first author.

To the Postgraduate Program in Agricultural Engineering at the Federal University of Campina Grande for the support in carrying out this work.

\section{References}

Alonso-Miravalles, L., Zannini, E., Bez, J., Arendt, E. K. \& O'Mahony, J. Á. (2020). Physical and flow properties of pseudocereal-based protein-rich ingredient powders. Journal of Food Engineering, 281:109973.

AS- Australian Standart. (1996) AS 3774: Loads on bulks containers.

ASAE - American Society of Agricultural Engineers (1988). "Loads exerted by freeflowing grain on bins.” ANSI/ASAE EP433 DEC 1988 (R2001), St. Joseph, MI.

Baroni, G. D., Benedeti, P. H. \& Seidel, D. J. (2017). Cenários prospectivos da produção e armazenagem de grãos no Brasil. Revista Thema, 14(4), 55-64.

Batista, C. S. Estudo teórico e experimental do fluxo de sólidos particulados em silos verticais. Campina Grande: UFCG. 81p. Tese (Doutorado em Engenharia de Processos), 2009.

Cabrejos Marín, F. (2018). Gravity reclaim stockpiles: What you need to know. Particulate Science \& Technology, 36(4), 473-480.

Calderón, C. A., Olivares, M. C. V., Uñac, R. O. \& Vidales, A. M. (2017). Correlations between flow rate parameters and the shape of the grains in a silo discharge. Powder Technology, 320, 43-50.

Calil Júnior, C. \& Cheung, A. B. (2007). Silos: Pressões, fluxo, recomendações para o projeto e exemplos de cálculo. 232p.

Calil, C.J. (1982). Sobrepresiones en las Paredes de los Silos para almacenamiento de Productos Pulverulentos Cohesivos. Tese (Doutoramento) - Escola Técnica Superior de Engenheiros Industriais de Barcelona, Universidade Politécnica de Barcelona.

Calil Júnior, C. (1990). Recomendações de fluxo e de cargas para o projeto de silos verticais. Tese (Livre Docência) - Escola de Engenharia de São Carlos, Universidade de São Paulo.

Canal Rural. (2016). Homem é soterrado após desabamento de silo em Mato Grosso. https://www.canalrural.com.br/noticias/homem-soterrado aposdesabamento-silo-mato-grosso-64848/.

Cao, Q. \& Zhao, Y. (2017). Buckling design of large steel silos with various slendernesses. Journal of Zhejiang University-SCIENCE (Applied Physics \& Engineering), 18(4), 282-305.

Chen, X., Xu, Y., Lu, H. \& Guo, X. (2018). Effect of the moisture content of straw on the internal friction angle of a granular biomass-coal system, Fuel, 215, $266-271$.

Cheung, A. B., Calil Júnior, C., \& Bertocini, S. R. (2015). Investigação estrutural de silos metálicos e de concreto no Brasil. In Anais CONPAT. 
Research, Society and Development, v. 10, n. 8, e14510817253, 2021

(CC BY 4.0) | ISSN 2525-3409 | DOI: http://dx.doi.org/10.33448/rsd-v10i8.17253

ClickPB. (2018). Silo de milho em fábrica de Campina Grande rompe e deixa um funcionário morto após soterramento. https://www.clickpb.com.br/paraiba/silo-de-milho-rompe-e-deixa-funcionarios-soterrados-em-fabrica-de-campina-grande-244527.html

Colonnelo, C. \& Kramár, M. (2018). Dynamics of silo deformation under granular discharge. Physical Review E. $98(5), 052902$.

CONAB - Companhia Nacional de Abastecimento (2021) Acompanhamento safra brasileira de grãos, v.8- Safra 2020/21, n. 4 - Quarto levantamento, 1-85, https://www.conab.gov.br/info-agro/safras/graos/boletim-da-safra-de-graos.

Deckers, H. P. F. (2014). Estudo teórico de pressões em silos esbeltos prismáticos com descarga excêntrica. UFLA. 146 p. Tese de Doutorado.

Dogangun, A., Karaca, Z., Durmus, A. M. \& ASCE, H. S. (2009). Cause of Da.mage and Failures in Silo Structures. Journal of Performance of Constructed Facilities, 23(2), 65-71.

EN 1991-4: EUROCODE 1. Actions on structures - Part 4: Silos and tanks. European Committee for Normalisation. 108 p.

Fürll, C. \& Hoffmann, T. (2015). Assessment of the flow properties of crushed grain products depending on the granulometric condition. Agricultural Engineering International, 17(4), 377-386.

Gaucha ZH. (2021). Homem morre soterrado em silo de grãos, em Ipê. Available in: https://gauchazh.clicrbs.com.br/pioneiro/geral/noticia/2021/01/homem morre-soterrado-em-silo-de-graos-em-ipe-ckk3y8fex000o019wqk0x7omt.html .

Guo, Z., Shan, Z., Du, D., Zhao, M. \& Zhang, M. (2018). Experimental investigation on the flow properties of sand granules in the process of sand mold printing. Rapid Prototyping Journal, 24(9), 1599-1608.

Hotala, E., Skotny, L., Kuśnierek, M. \& Boniecka, J. (2016). Experimental investigations on the resistance of vertical stiffeners of steel silos shells made of corrugated sheets. Boca Raton: Crc Press-Taylor \& Francis Group, 499-506.

Iqbal, T. \& Fitzpatrick, J. J. (2006). Effect of storage conditions on the wall friction characteristics of three food powders. Journal of Food Engineering, 72(3), $273-280$.

Iwicki, P., Rejowski, K. \& Tejchman, J. (2015). Stability of cylindrical steel silos composed of corrugated sheets and column s based on FE analyses versus Eurocode 3 approach. Engineering Failure Analysis, 57(1), 444-469.

Jager, P. D., Bramante, T. \& Luner, P. E. (2015). Assessment of pharmaceutical powder flowability using shear cell-based methods and application of Jenike's methodology. Journal of Pharmaceutical Sciences, 104(11), 3804-3813.

Jansseune, A. W. \& Belis, J. (2015). Elastic failure of locally supported silos with U-shaped longitudinal stiffeners. KSCE J Civ Eng, 19, 1041-1049.

Jenike, A. W. (1964). Storage and flow of silos. Salt Lake City. University of Utah. Bulletin 123. Engineering Experiment Station.

Kobyłka, R., Horabik, J. \& Molenda, M. (2017). Numerical simulation of the dynamic response due to discharge initiation of the grain silo. International Journal of Solids and Structures, 106, 27-37.

Kobyłkam R., Molenda, M. \& Horabik, J. (2020). DEM simulation of the pressure distribution and flow pattern in a model grain silo with an annular segment attached to the wall. Biosystems Engineering, 193, 75-89.

Liu, Y., Guo, X., Lu, H. \& Gonga, X. (2015). An investigation of the effect of particle size on the flow behavior of pulverized coal. Procedia Engineering, $102,698-713$.

Livaoglu, R. R. \& Durmus, A. (2016). A simplified approximation for seismic analysis of silo-bulk material system. Bull Earthquake Eng, $14,863-887$.

Lobato. J. C. M., F. Mascarenhas. F. P., Mesquita. A. L. A. \& Mesquita. A. L. A. (2016). Conical Hopper Design for Mass Flow - Case of red mud. Holos. 2, $120-131$

Lopes Neto, J. O., Nascimento, J. W. B. \& Fank, M. Z. (2014). Forças verticais e de atrito em silos cilíndricos com fundo plano. Revista Brasileira de Engenharia Agrícola e Ambiental, 18(6),652-657.

Lopes Neto, J. P. \& Nascimento, J. W. B. (2013). Características de fluxo e projeto de tremonhas cônicas em silos verticais. Revista Brasileira de Engenharia Agrícola e Ambiental, 17(3), 339-345.

Lopes Neto, J. P. \& Nascimento, J. W. B. (2018). Desastres com silos verticais no Brasil. Uma breve coletânea de acontecimetnos e suas causas. Congresso Técnico Científico da Engenharia e da Agronomia - CONTECC'2018 - Maceio - AL.

Lopes Neto, J. P. (2009). Análise teórico experimental das forças verticais e de atrito em silos cilíndricos. Engenharia de Processos, Universidade Federal de Campina Grande. Tese de doutorado.

Lopes Neto, J. P., Nascimento, J. W. B. do, Silva, V. R. da, \& Lopes, F. F. de M. (2007). Propriedade de fluxo e característica de escoabilidade de rações avícolas para dimensionamento de silos. Ciência e Agrotecnologia, 31(3), 851-859.

Lopes Neto, J., Nascimento, J. W. B. do, \& Fank, M. Z. (2014). Forças verticais e de atrito em silos cilíndricos com fundo plano. Revista Brasileira de Engenharia Agrícola e Ambiental, 18(6), 652-657.

Ludke, M. \& Andre, M. E. D. A. (2013). Pesquisas em educação: uma abordagem qualitativa. E.P.U.

Madrona, F. S. \& Calil Junior, C. (2009). Análise das pressões em silos esbeltos com descarga excêntrica. Cadernos de Engenharia de Estruturas, 11(49), 3756. 
Maiti, R., Das, G. \& Das, P.K. (2016). Experiments on eccentric granular discharge from a quasi-two-dimensional silo, Powder Technology, 301, 1054-1066

Malagalage, A., Ratnayake, C., Saasen, A., Thomassen, T.\& von-Hafenbrädl, F. O. (2018). Flow properties of drill cuttings with varying drilling fluid contente using jenike shear testing. Chemical Engineering \& Technology, 41(8), 1544-1550.

Medeiros, I. F. (2012). Características de fluxo e vazão de descarga em silos verticais. Dissertação de Mestrado. Universidade Federal de Campina Grande, Campina Grande, PB, Brasil.

Mehretehran, A. M. \& Maleki, S. (2018). 3D buckling assessment of cylindrical steel silos of uniform thickness under seismic action. Thin-Walled Structures, $131,654-667$.

Mellmann, J., Hoffmann, T. \& Fürll, C. (2013). Flow properties of crushed grains as a function of the particle shape, Powder Technology, 249, $269-273$.

Mitra, H., Pushpadass, H. A., Franklin, M., Ambrose, R. P., Ghoroi, C. \& Battula, S. N. (2017). Influence of moisture content on the flow properties of basundi mix. Powder Technology, 312, 133-143.

Nascimento, J. W. B. Estudos dos silos metálicos prismáticos para fábricas de ração. São Carlos: Escola de Engenharia de São Carlos - Universidade de São Paulo, 152p. Tese de Doutorado, 1996.

O Bem Dito. (2017). Trabalhador morre soterrado por farelo de trigo após silo desabar. Available in: https://www.obemdito.com.br/cotidiano/trabalhador morre-soterrado-por-farelo-de-trigo-apos-silo-desabar/9863/. Access on: 03 of january 2021.

Oginni, O. \& Fasina, O. (2018). Theoretical estimation of silo design parameters for fractionated loblolly pine grinds - Moisture content and particle size effects. Industrial Crops and Products, 123, 379-385.

Park, H. W., Kim, S. T., Choung, M. G., Han, W.-Y. \& Yoon, W. B. (2016). Flow Behavior of Adzuki Bean Flour. Journal of Food Process Engineering, 39(4), 366-376.

Paula, W. C. (2020). Influência da geometria de tremonhas concêntricas e excêntricas nos esforços de silos esbeltos metálicos UFLA. Tese de Doutorado.

Pereira, A. S., Shitsuka, D. M., Parreira, F. J. \& Shitsuka, R. (2018). Metodologia da pesquisa científica. UFSM.

Portal Tchê. (2019). Jovem morre após desabamento de silo em Passo Fundo. https://portaltche.com.br/arquivos/16024.

Ravenet, J. (1983) - Silos: flujo de vaciado de sólidos, formacion de bovedas. Editores Técni-cos Asociados, 330p.

Rejowski, K., \& Iwicki, P. (2016). Simplified stability analysis of steel cylindrical silos with corrugated walls and vertical columns. 13th International Conference on Metal Structures (ICMS), 525-532.

Ripp, M., Debele, Z. A., \& Ripperger, S. (2015). Determination of Bulk Flow Property of tef Flour and Seed and Design of a Silo. Particulate Science \& Technology, 33(5), 494-502.

Rodrigues, A. C. A. (2019). Estudo da instabilidade das colunas (montantes) de silos metálicos cilíndricos de chapas onduladas. Dissertação de Mestrado, Escola de Engenharia de São Carlos, Universidade de São Paulo, São Carlos.

Sadowski, A. J. \& Rotter, J. M. (2011). Buckling of very slender metal silos under eccentric discharge, Engineering Structures, 33(4), 1187-1194.

Sielamowicz, I., Czech, M. \& Kowalewski, A. T. (2010). Empirical description of flow parameters in eccentric flow inside a silo model, Powder Technology, 198(3), 381-394.

Siliveru, K., Ambrose, R. P. K., Vadlani P. V. (2017). Significance of composition and particle sizeon the shear flow properties of wheat flour. J Sci Food Agric, 97, 2300-2306.

Silva, F. S., Correa, P. C., Calil Junior, C. \& Gomes, F. C. (2011). Análise dos coeficientes de atrito estático e dinâmico de grãos de café com pergaminho, determinados em diferentes equipamentos, teores de água e materiais de parede. Revista Brasileira de Produtos Agroindustriais, 13(2), 143-156.

Silva, L. A. (2019). Efeito de inserts no padrão de fluxo e vazão mássica em silo vertical esbelto para farinha de milho flocada. Dissertação de Mestrado. Universidade Federal de Campina Grande, Campina Grande, PB, Brasil.

Sondej, M., Iwicki, P., Tejchman, J. \& Wójcik, M. (2015). Critical assessment of Eurocode approach to stability of metal cylindrical silos with corrugated walls and vertical stiffeners, Thin-Walled Structures, 95, 335-346.

Souza, G. F. M. V., Miranda, R. F.\& Barrozo, M. A. S. (2015). Soybean (Glycine max L. Merrill) Seed Drying in Fixed Bed: Process Heterogeneity and Seed Quality. Drying Technology, 33(14), 1779-1787.

Stasiak, M., Molenda, M., Bańda, M. \& Gondek, E. (2015). Mechanical properties of sawdust and woodchips. Fuel, 159, 900-908.

Tangará em foco. (2020). Vídeo: trabalhador filma momento em que silo com milho estoura em Mato Grosso. https://tangaraemfoco.com.br/2020/08/15/videotrabalhador-filma-momento-em-que-silo-com-milho-estoura-em-mato-grosso.html.

Tascón, A. (2017). Design of silos for dust explosions: Determination of vent area sizes and explosion pressures. Engineering Structures, 134, 1-10.

Zaccari, N. \& Cudemo, M. (2016). Steel silo failure and reinforcement proposal, Engineering Failure Analysis, 63, 1-11. 